

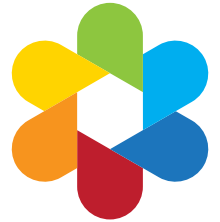

* Doutor em Física. Professor Emérito da Universidade Federal de Sergipe. Aracaju, Sergipe, Brasil. E-mail: fernandeslima44@hotmail. com

**Especialista em Educação Profissional. Titular da Cadeira 28 da Academia Paulista de Educação. Peabiru Educacional. São Paulo, São Paulo, Brasil. E-mail: facordao@uol.com. br

Recebido para publicação em: 1.8.2016

Aprovado em: 3.3.2017

\section{DESAFIOS DA EDUCAÇÃO PROFISSIONAL TÉCNICA DE NÍVEL MÉDIO} CHALLENGES OF HIGH SCHOOL TECHNICAL
VOCATIONAL EDUCATION

DESAFIOOS DE LA EDUCACIÓN DE NIVEL SECUNDARIO CON MODALIDAD TÉCNICO PROFESIONAL

José Fernandes de Lima*

Francisco Aparecido Cordão**

\section{Resumo}

Neste trabalho, discute-se a importância da formação de pessoal para o desenvolvimento econômico e social do País, analisa-se a disponibilidade de pessoal para o trabalho e para a inovação, confronta-se a organização da educação profissional técnica de nível médio brasileira com a de outros países e identificam-se alguns desafios que devem ser enfrentados no caminho da oferta de uma educação profissional de qualidade, capaz de promover a inovação e a sustentabilidade da economia nacional.

Palavras-chave: Educação para o trabalho. Educação profissional. Ensino médio.

\section{Abstract}

In this paper, we discuss the importance of training personnel for the economic and social development of the country, as well, analyze the availability of work personnel staff and innovation, compare the organization of Brazilian high school level professional technical education with the other countries and identify some challenges that must be faced on the path to offer quality vocational education, that can promote innovation and sustainability for the national economy.

Keywords: Education for work. Vocational education. High school. 


\section{Resumen}

En este trabajo se discute la importancia de la formación de personal para el desarrollo económico y social del País, se analiza la disponibilidad de personal para el trabajo y para la innovación, se compara la organización de la educación secundaria con modalidad técnico profesional brasileña con la de otros países y se identifican algunos desafíos que han de enfrentarse con vistas a ofertar una formación profesional de calidad, capaz de promover la innovación y la sustentabilidad de la economía nacional.

Palabras clave: Educación laboral. Formación profesional. Educación secundaria.

\section{Introdução}

As economias centrais adotam um padrão de crescimento industrial e de serviços que favorece os setores intensivos em tecnologia de ponta. O ciclo dos produtos torna-se cada vez menor, bem como decresce o tempo despendido entre a fase do desenvolvimento e a comercialização. A sobrevivência nesse ambiente requer uma estratégia de diversificação de investimentos e um forte investimento na formação e qualificação profissional.

O modelo de desenvolvimento caracterizado pelo forte conteúdo científico e pela especialização define relações cada vez mais estreitas entre capacidade científica, desenvolvimento tecnológico e crescimento econômico. Como consequência, exige dos países que desejem adotá-lo uma política científica e tecnológica articulada com as políticas econômica e industrial e um projeto centrado na profissionalização das pessoas.

As inovações tecnológicas promovidas pelos países desenvolvidos tendem a acentuar a desigualdade e a dependência tecnológica e, em certos casos, a provocar instabilidade política nos países em desenvolvimento. Indicadores de crescimento demonstram que, atualmente, a inovação contribui com mais da metade do produto interno bruto dos países desenvolvidos. Isso torna a inovação um dos fatores decisivos para o desenvolvimento econômico e social de uma nação. Para o Brasil, o desafio da inovação tecnológica é fundamental para definir sua efetiva inclusão em um cenário internacional desenvolvimentista.

O conceito de inovação é, neste caso, visto de uma forma ampla, que contempla não só os grandes saltos, mas também, as mudanças incrementais, as novas finalidades, a melhoria da gestão, os novos modelos de negócio e a conquista de novos mercados.

B. Téc. Senac, Rio de Janeiro, v. 43, n. 1, p. 78-109, jan./abr. 2017. 
Entre os principais ingredientes para criação de um ambiente de inovação, identificam-se a necessidade de uma agenda de pesquisa e desenvolvimento e a definição de uma política destinada objetivamente para a formação de pessoal, capaz de suprir as novas demandas do mundo do trabalho. Sem investimento na formação de pessoal, é difícil estimular a inovação nas empresas, bem como torná-las mais competitivas.

Para criar um ambiente de inovação, o país necessita investir em educação, notadamente em educação científica, em todos os níveis, da pré-escola à pós-graduação. Necessita aumentar o número médio de anos de escolaridade da população e fazer crescer o indicador de alfabetização científica.

Para manter um parque industrial e de serviços competitivo, o país necessita investir na formação de engenheiros e técnicos qualificados, com capacidade de incorporar as novas tecnologias e entender os novos processos desenvolvidos, em condições de gerar novíssimas tecnologias. A formação de pessoal para enfrentar esses novos desafios tem sido uma preocupação constante, notadamente, nos países desenvolvidos. No Brasil, a profissionalização virou uma das cláusulas pétreas da Constituição federal, a qual, de acordo com seu Art. 227, é um "dever da Família, da Sociedade e do Estado", e deve ser assegurada "com absoluta prioridade" (BRASIL, 1988).

A preocupação com a educação profissional técnica de nível médio tem mobilizado esforços de gestores e educadores de todo o planeta e influenciado reformas educativas em vários países. Tomando como ponto de partida a preocupação com a empregabilidade dos jovens, várias organizações, a exemplo da Organização para a Cooperação e Desenvolvimento Econômico (OCDE), do Banco Mundial e da Organização das Nações Unidas para a Educação, a Ciência e a Cultura (Unesco), têm produzido documentos que apontam para a necessidade de urgentes reformas, especialmente, no tocante à organização educacional e aos currículos escolares.

Este artigo analisa a formação para o trabalho praticada no Brasil nos diversos níveis de ensino, efetua uma comparação do modelo brasileiro de educação profissional técnica de nível médio com alguns modelos adotados em outros países e lista alguns desafios que se apresentam para a educação profissional na perspectiva do cumprimento da Constituição federal que no seu Artigo 205, define que:

a Educação, direito de todos e dever do Estado e da Família, será promovida e incentivada com a colaboração da sociedade, visando ao pleno desenvolvimento da pessoa, seu preparo para o exercício da cidadania e sua Qualificação para o Trabalho (BRASIL, 1988). 


\section{Disponibilidade de pessoal para o trabalho e para a inovação}

O Brasil estruturou o seu desenvolvimento industrial com base na importação de tecnologia. Essa condição de importador de tecnologia permitiu que, durante muito tempo, utilizasse mão de obra pouco qualificada e praticasse a competitividade com base no barateamento dos custos com pessoal.

Até o último quartil do século 20, a formação profissional, no Brasil, limitava-se ao treinamento operacional para produção em série e padronizada, com incorporação maciça de operários semiqualificados. Os trabalhadores tinham pouca margem de autonomia, as decisões cabiam aos gerentes detentores dos conhecimentos tecnológicos e gerenciais.

A partir das décadas de 70 e 80 do último século, estudos realizados em diversas partes do planeta sobre os impactos das novas tecnologias revelaram a necessidade de profissionais cada vez mais polivalentes e capazes de interagir em situações novas e em um ambiente sujeito a constante mutação. As empresas passaram a exigir trabalhadores mais qualificados e detentores de maior autonomia. No entender dessas empresas, as novas funções requerem uma formação profissional que vá além do domínio operacional de um determinado ofício, que possibilite alcançar uma compreensão global do processo produtivo.

Nos últimos anos, o Brasil modificou a sua consciência a respeito da necessidade de investir na criação de um ambiente de inovação para promoção do desenvolvimento econômico. A condição de país pertencente às dez maiores economias do globo impõe que o Brasil migre rapidamente da posição de importador de tecnologia para a de produtor de tecnologia.

Para tanto, o país precisa ter em conta que a inovação acelerada praticada pelos países desenvolvidos provoca a obsolescência dos equipamentos industriais e também dos processos de produção e que, não desejando ficar para trás, o país precisa investir fortemente em educação, concebida como processo único e sistêmico, desde a educação infantil até a pós-graduação. É preciso formar mestres e doutores de alta qualidade para liderar as pesquisas de ponta, formar mais engenheiros capazes de traduzir as descobertas científicas em novos produtos e processos e formar um grande contingente de técnicos, bem como qualificar seus auxiliares, para fazer funcionar com mais qualidade as indústrias no país.

O conceito de inovação vem, aos poucos, sendo incorporado aos investimentos brasileiros. Tem crescido o número de parques tecnológicos, bem como o número de incubadoras de empresa. Tem, também, crescido o entendimento de que o uso da ciência e da tecnologia como fonte de riquezas
A inovação acelerada praticada pelos países desenvolvidos provoca a obsolescência dos equipamentos industriais e também dos processos de produção

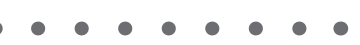


é crucial para que as demandas de tecnologia e inovação sejam produzidas em um contexto de atendimento aos projetos empresariais e às políticas sociais. Cresce o entendimento de que o país precisa aproximar a academia da empresa.

Parte do relativo sucesso obtido, recentemente, no tocante à aproximação universidade-empresa, decorre de um conjunto de instrumentos de fomento, de oferta de crédito, de subvenções concedidas e da criação de novas leis, que visam facilitar essa aproximação mediante a diminuição dos entraves burocráticos.

Apesar do crescimento verificado nos últimos anos, o percentual de doutores trabalhando na indústria ainda é pequeno e gira em torno dos 7,1\%. Esse percentual mostra-se pequeno quando comparado com a Alemanha, que tem 26,7\%, Estados Unidos 7,7\%, Japão 14,2\%, Coreia 40,0\% e Canadá $63 \%$. Acrescente-se que, nos Estados Unidos e na Alemanha, mais de 60\% dos dispêndios em inovação são feitos pelo setor empresarial privado, enquanto, no Brasil, os investimentos feitos em inovação pelo setor empresarial como um todo é inferior a 37\% (SENAI, 2015).

De acordo com estudo do Centro de Gestão e Estudos Estratégicos (CGEE), realizado com base nos dados do Censo Demográfico de 2010, o Brasil tem 187.354 doutores e 516.983 mestres, sendo que 168.143 doutores foram formados depois de 1996 (GALVÃO, 2016).

Quando se confronta o número de doutores por 100 mil habitantes no Brasil e em outros países, verifica-se que ainda há um grande percurso no caminho: enquanto o Brasil tem 7,6 doutores por 100 mil habitantes, a Eslovênia tem 56,6; o Reino Unido, 41; Portugal, 40; Finlândia, 35; França, 21 e Estados Unidos, também 21 (GALVÃO, 2016). O número total de cientistas e engenheiros no Brasil é 20 vezes menor do que nos Estados Unidos e no Japão. Estes dados podem estar relacionados com o baixo número de patentes registradas pelo Brasil.

Quando o país trata da formação de recursos humanos no nível de graduação, também encontra um quadro que necessita melhorar. Somente 16,7\% dos jovens de 18 a 24 anos estão matriculados no ensino superior. Na Argentina, esse percentual é de 30\%; no Chile, é de 52\% e nos Estados Unidos, de $60 \%$. Além disso, somente $14 \%$ dos estudantes brasileiros matriculados no ensino superior estão nos cursos de Engenharia, Produção e Construção.

O Plano Nacional de Educação (PNE) 2014-2024 estabelece, na meta 12:

elevar a taxa bruta de matrícula na educação superior para $50 \%$ e a taxa líquida para 33\% da população de 18 a 24 anos, assegurada a qualidade da oferta e a expansão, para, 
pelo menos, $40 \%$ das matrículas no segmento público (BRASIL, 2014).

O atingimento dessa meta demandará um grande esforço de toda a sociedade, seja no tocante à construção de novas escolas, seja na formação e contratação de novos professores ou na reestruturação dos currículos escolares.

A carência de profissionais técnicos de nível médio é proporcionalmente muito maior do que a verificada no nível superior. Dados da Pesquisa Nacional por Amostra de Domicílios (PNAD) de 2014 mostram que apenas $31,1 \%$ dos trabalhadores brasileiros possuem nível médio completo (IBGE, 2015). Muitas vezes menor é o percentual dos que possuem educação profissional técnica.

O percentual de matrículas na educação profissional técnica de nível médio em relação ao total de matrículas no ensino médio vem crescendo desde 2007 (11\%), tendo atingido, em 2015, o percentual de 19,1\%. Dos 1.787.229 matriculados, 391.766 estavam no ensino médio integrado à educação profissional, 1.023.212 na forma concomitante e 93.919 na modalidade normal/magistério. A análise por atribuição administrativa mostra que, do total das matrículas, 945.770 estavam matriculados na rede pública e 841.459 na rede privada (INEP, 2016).

O PNE para o decênio 2014-2024 trata da qualificação profissional, incluindo a formação inicial e a formação continuada de trabalhadores nas metas 8 a 11. A meta 8 propõe elevar a escolaridade média da população de 18 a 29 anos, de modo a alcançar, no mínimo, 12 anos de estudo no último ano de vigência do PNE. Entre as estratégias estabelecidas para o atingimento dessa meta está a expansão da oferta gratuita de educação profissional técnica por parte das entidades privadas de serviço social, na forma concomitante ao ensino ofertado na rede escolar pública.

Nas estratégias definidas para o atingimento da meta 9, destaca-se a que propõe implementar programas de capacitação tecnológica da população jovem e adulta.

A meta 10, por seu turno, determina oferecer, no mínimo, 25\% das matrículas de educação de jovens e adultos, nos ensinos fundamental e médio, na forma integrada à educação profissional.

A meta 11 propõe triplicar as matrículas da educação profissional técnica de nível médio. Como estratégia, propõe, entre outras ações, utilizar a modalidade de educação a distância.

\section{A carência de profissionais técnicos de nível médio é proporcionalmente muito maior do que a verificada no nível superior

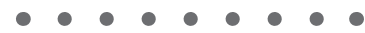




\section{Panorama global da educação profissional técnica de nível médio}

A intensa disseminação de tecnologias e o uso cada vez mais frequente de computadores nas linhas de produção estabelecem uma relação direta entre as mudanças nos processos de trabalho e a necessidade de maior qualificação profissional. Essa relação cria um novo vínculo entre a escolarização geral da população e o desenvolvimento econômico dos países. Essa nova configuração evidencia a necessidade de investimentos na reestruturação dos sistemas educacionais.

Os desafios identificados possuem em comum os temas referentes aos currículos escolares, à gestão, ao aumento das exigências das empresas e à relação com a educação básica.

É sabido que a introdução de mudanças no modelo de educação profissional para um determinado país deve considerar, sobremaneira, sua evolução histórica e sua vocação. Isso implica dizer que nem sempre é possível transplantar um modelo educacional de um país para outro.

As informações apresentadas a seguir sobre alguns sistemas educacionais têm a finalidade única de oferecer subsídios para análise comparativa do quadro brasileiro (SENAI, 2015).

Inglaterra - Na Inglaterra, a educação compulsória vai até os 18 anos de idade. A preparação para o trabalho é antiga. Teve início com o treinamento compulsório das crianças nos trabalhos domésticos e na agricultura. O modelo inglês é um modelo descentralizado, que valoriza mais a experiência de trabalho do que a certificação. Tem pouca participação do Estado, tanto no financiamento quanto na regulação.

As críticas que, atualmente, são direcionadas ao modelo inglês, referem-se, principalmente, ao sistema descentralizado, que torna o controle da oferta precário, o que resulta no excesso de profissionais em determinadas áreas enquanto outras áreas acusam faltas.

Outra crítica refere-se à pulverização de cursos, a qual dificulta o aproveitamento do aluno formado em outros cursos ou outros temas de áreas correlatas. A grande quantidade de opções acaba não sendo do conhecimento nem dos estudantes nem das empresas. O modelo ressente-se de maior integração com a educação básica que, por sua vez, apresenta resultados insatisfatórios. 
França - O modelo educacional adotado na França é estatal. Como o Estado era forte, a escola pública universal tornou-se a base do sistema. O modelo é centralizado e executado prioritariamente por meio das escolas públicas. A escola é única até os 14 anos de idade. A partir dos 15, são oferecidas diversas opções de educação profissional e educação geral. Os alunos que obtêm as melhores notas são direcionados para a educação geral e educação superior. No sistema educacional francês, 37\% dos estudantes optam pela educação profissional, notadamente, aqueles estudantes com menores índices de avaliação.

Há também a educação profissional destinada ao público adulto, oferecida por outro ministério, que corresponde, naquele país, ao que era o Ministério do Trabalho e Emprego no Brasil. A centralização e a estatização têm sido motivo de crescentes críticas.

Alemanha - O modelo adotado é conhecido como dual. Combina o preparo para o trabalho, simultaneamente, na escola e na empresa. As proporções de educação básica e educação profissional podem variar de região para região.

Na Alemanha, os profissionais técnicos são muito prestigiados. A procura pela educação profissional é grande, ultrapassa o percentual de $51 \%$. Os estudantes optam pela educação profissional no fim da educação primária (aos 11 ou 12 anos de idade) e isso tem sido bastante questionado, principalmente por ser o momento da decisão considerado muito precoce.

Estados Unidos - O sistema educacional dos Estados Unidos é bastante descentralizado, em virtude da autonomia que detêm cada estado daquela Federação. Os estados possuem total autonomia para definir suas políticas educacionais, sem interferência direta da União.

O sistema educacional americano objetiva assegurar a universalização da educação básica, considerada essencial e necessária para obtenção de emprego. Uma característica geral desse sistema é a flexibilidade, decorrente da adoção do modelo de escola compreensiva, que permite que uma mesma escola prepare para a universidade, para o exercício profissional ou ofereça uma formação menos exigente, para os alunos de menor aproveitamento.

No tocante à formação profissional, o modelo americano é antigo. Vem desde o século 19. A preparação para o trabalho fica a cargo das escolas. A educação profissional julga-se prejudicada pela educação regular, porque esta última é fraca, principalmente em relação aos alunos de menor rendimento.

As últimas recomendações produzidas por especialistas daquele país sugerem aumentar o uso dos locais de trabalho pelas escolas e melhorar as 
habilidades em letramento e aritmética. As recomendações indicam que a formação profissional precisa ser cada vez mais longa e mais complexa.

China - Na China, a educação é estatal. A oferta de educação profissional é limitada, principalmente porque é mais dispendiosa. Nos últimos anos, tem havido um crescimento da oferta de educação profissional. Esse crescimento decorre de algumas ações do Estado. Têm sido criadas escolas politécnicas e vocacionais.

O incentivo à educação profissional se dá no sentido de estabelecer uma gestão escolar mais flexível e de ajustar a oferta com as demandas do mercado.

Há uma dificuldade em atrair professores para a Educação Profissional e Tecnológica (EPT) porque as áreas acadêmicas têm mais prestígio.

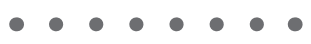

O incentivo

à educação profissional se dá no sentido de estabelecer uma gestão escolar mais flexível e de ajustar a oferta com as demandas do mercado
Entre os desafios atualmente identificados pela China, destacam-se a necessidade de aperfeiçoar a cooperação das escolas com os empregadores e o estabelecimento de padrões para o treinamento e os estágios.

Coreia do Sul - Na Coreia, a escola elementar começa aos sete anos de idade e vai até os 12 anos. A creche, que vem antes, é opcional. A escola primária vai dos 13 aos 15 anos. Em seguida, vem o ensino médio, o “junior college" e a universidade.

Na passagem da escola elementar para escola primária (quando o estudante completa 12 anos), há uma prova com base na qual os melhores estudantes são direcionados às escolas acadêmicas e os outros às escolas das indústrias. Ao completar 18 anos, o jovem que deseje prosseguir seus estudos pode ir para a faculdade acadêmica, para uma faculdade de cursos mais curtos ou para uma faculdade industrial.

A educação acadêmica exerce forte atratividade e absorve os alunos mais talentosos. Como decorrência desse fato, o número de profissionais técnicos de nível médio é comparativamente muito pequeno.

Finlândia - A educação, na Finlândia, pende para o treinamento na empresa e a valorização da educação profissional dos 16 aos 19 anos.

O trânsito entre a educação acadêmica e a profissional é facilitado. Ao mesmo tempo que investe na educação profissional, seus alunos da educação regular tiram os melhores resultados no Programa Internacional de Avaliação de Estudantes (Pisa). Os currículos valorizam, além das capacidades cognitivas, as socioemocionais. 
A carreira de professor é altamente valorizada e as exigências para ensinar na educação acadêmica e na profissional são as mesmas. A qualificação profissional, na Finlândia, enfrenta problemas por causa do envelhecimento da população e da diminuição do número de jovens. Por isso, o país investe na flexibilidade, para permitir que os estudantes frequentem mais de uma escola.

As últimas orientações da Finlândia são no sentido de elevar e definir as qualificações dos estudantes da educação secundária em geral, desenvolver novos processos de orientação e aconselhamento dos jovens e criar facilidades para que todos terminem seus cursos.

Estes dados mostram que os países desenvolvidos utilizam basicamente três modelos: o modelo que valoriza as atividades acadêmicas; o modelo não formal, que oferta programas de diferentes formas e duração variadas; e o chamado modelo dual, que combina educação profissional com atividades no trabalho. Diante das novas exigências trazidas pelas modificações do mundo do trabalho, todos eles estão sofrendo pressão para realização de novos ajustes.

\section{Organização da educação profissional técnica de nível médio no Brasil}

O modelo de educação profissional técnica adotado no Brasil seguiu dois caminhos distintos: o modelo das Escolas Técnicas Federais, que se assemeIha ao modelo francês; e o dos Serviços Sociais Autônomos, que é inspirado no modelo alemão. Os cursos que, no início, eram destinados unicamente à formação profissional, foram, aos poucos, incorporando componentes da educação formal.

O financiamento da educação profissional advém, majoritariamente, do Governo Federal, no caso das escolas técnicas mantidas pela União. Ultimamente, a República tem investido, também, além de sua Rede Federal, em instituições educacionais mantidas pela iniciativa privada, para oferta de cursos técnicos de nível médio e de qualificação profissional, incluindo a formação inicial e continuada, no âmbito do Programa Nacional de Acesso ao Ensino Técnico e Emprego (Pronatec), instituído pela Lei n. 12.513/2011 e complementado pela Lei n. 12.816/2013. No caso dos cursos oferecidos pelos Serviços Sociais Autônomos, os mesmos são financiados de acordo com um sistema específico, concebido na década de 1940, pelo Governo Getúlio Vargas, que integra contribuições compulsórias dos empregadores sobre a folha de salários de seus empregados, destinadas à manutenção de entidades privadas de Serviço Social e de Educação Profissional, as quais são 


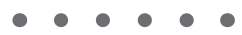

A qualidade da educação profissional brasileira é diretamente afetada pela qualidade da educação básica denominada regular vinculadas ao Sistema Sindical Nacional em sua administração de natureza privada, com fiscalização da União. O chamado "Sistema S" foi subsumido e se encontra amparado pelo Artigo 240 da Constituição federal. O Artigo 20 da Lei n. 12.513/2011, com redação alterada pela Lei n. 12.816/2013 definiu regras específicas para incorporação dessas instituições de educação profissional no Sistema Federal de Ensino, na condição de mantenedoras, para também poder receber financiamentos específicos para atuação no âmbito do Pronatec, ofertando cursos técnicos de nível médio e cursos de qualificação profissional, incluindo a formação inicial e a formação continuada de trabalhadores. Nos últimos anos, tem aumentado, também, a oferta de educação profissional técnica de nível médio e seus respectivos itinerários formativos por parte dos sistemas estaduais de ensino e de ciência e tecnologia.

O padrão de ensino oferecido pelas escolas técnicas é considerado de boa qualidade e o mesmo ocorre com o chamado "Sistema S", cujos alunos têm sido premiados em competições internacionais.

Uma crítica que tem sido feita à educação profissional técnica desenvolvida no Brasil diz respeito ao fato de o número de estudantes da educação profissional ser considerado muito pequeno para alavancar o desenvolvimento do país. Há quem afirme que o País sabe produzir negócios muito bons para poucos, mas não sabe estender esses serviços para a maioria da população.

Apesar da participação dos estados haver crescido nos últimos tempos, o percentual de matrículas na educação profissional ainda é baixo e, como consequência, o número de formados nos cursos técnicos é muito pequeno.

Os baixos percentuais de matrículas na educação profissional têm sido atribuídos a vários motivos, entre os quais a baixa atratividade da educação profissional, a falta de oferta e a relação insatisfatória com a empregabilidade.

A qualidade da educação profissional brasileira é diretamente afetada pela qualidade da educação básica denominada regular. As carências da educação básica podem ser verificadas quando se observa que apenas $50 \%$ das pessoas de 15 a 17 anos (idade esperada) estão no ensino médio e que, ao terminarem o ensino médio, apenas $9 \%$ aprenderam o esperado em matemática.

Os marcos legais da educação profissional e tecnológica estão definidos nos Artigos 39, 40, 41 e 42 da Lei de Diretrizes e Bases da Educação Nacional (LDB).

Art. 39 - A educação profissional e tecnológica, no cumprimento dos objetivos da educação nacional, integra-se aos diferentes níveis e modalidades de educação e às dimensões do trabalho, da ciência e da tecnologia. 
$\S 1^{\circ}$ Os cursos de educação profissional e tecnológica poderão ser organizados por eixos tecnológicos, possibilitando a construção de diferentes itinerários formativos, observadas as normas do respectivo sistema e nível de ensino.

$\S 2^{\circ} \mathrm{A}$ educação profissional e tecnológica abrangerá os seguintes cursos:

I - de formação inicial e continuada ou qualificação profissional;

II - de educação profissional técnica de nível médio;

III - de educação profissional tecnológica de graduação e pós-graduação.

$\S 3^{\circ}$ Os cursos de educação profissional tecnológica de graduação e pós-graduação organizar-se-ão, no que concerne a objetivos, características e duração, de acordo com as diretrizes curriculares nacionais estabelecidas pelo Conselho Nacional de Educação.

Art. 40 - A educação profissional será desenvolvida em articulação com o ensino regular ou por diferentes estratégias de educação continuada, em instituições especializadas ou no ambiente de trabalho.

Art. 41 - O conhecimento adquirido na educação profissional e tecnológica, inclusive no trabalho, poderá ser objeto de avaliação, reconhecimento e certificação para prosseguimento ou conclusão de estudos.

Art. 42 - As instituições de educação profissional e tecnológica, além dos seus cursos regulares, oferecerão cursos especiais, abertos à comunidade, condicionada a matrícula à capacidade de aproveitamento e não necessariamente ao nível de escolaridade (BRASIL, 1996).

No caso específico da educação profissional técnica de nível médio, faz-se necessário, ainda, observar que a Lei n. 11.741/2008 introduziu na LDB, aprovada em 1996, uma Seção IV-A, intitulada "Da Educação Profissional Técnica de Nível Médio", acrescentando os seguintes Artigos: 36-A, 36-B, 36-C e 36-D.

Art. 36-A - Sem prejuízo do disposto na seção IV deste capítulo, o ensino médio, atendida a formação geral do educando, poderá prepará-lo para o exercício de profissões técnicas.

Parágrafo único. A preparação geral para o trabalho e, facultativamente, a habilitação profissional poderão ser desenvolvidas nos próprios estabelecimentos de ensino médio ou em cooperação com instituições especializadas em educação profissional. 
Art. 36-B - A educação profissional técnica de nível médio será desenvolvida nas seguintes formas:

I - articulada com o ensino médio;

II - subsequente, em cursos destinados a quem já tenha concluído o ensino médio.

Parágrafo único. A educação profissional técnica de nível médio deverá observar:

I - os objetivos e definições contidos nas diretrizes curriculares nacionais estabelecidas pelo Conselho Nacional de Educação;

II - as normas complementares dos respectivos sistemas de ensino;

III - as exigências de cada instituição de ensino, nos termos de seu projeto pedagógico.

Art. 36-C - A educação profissional técnica de nível médio articulada, prevista no inciso I do caput do art. 36-B desta lei, será desenvolvida de forma:

I - integrada, oferecida somente a quem já tenha concluído o ensino fundamental, sendo o curso planejado de modo a conduzir o aluno à habilitação profissional técnica de nível médio, na mesma instituição de ensino efetuando-se matrícula única para cada aluno;

II - concomitante, oferecida a quem ingresse no ensino médio ou já o esteja cursando, efetuando-se matrículas distintas para cada curso, e podendo ocorrer:

a) na mesma instituição de ensino, aproveitando as oportunidades educacionais disponíveis;

b) em instituições de ensino distintas, aproveitando-se as oportunidades educacionais disponíveis;

c) em instituições de ensino distintas, mediante convênios de intercomplementaridade, visando ao planejamento e ao desenvolvimento de projeto pedagógico unificado.

Art. 36-D - os diplomas de cursos de educação profissional técnica de nível médio, quando registrados, terão validade nacional e habilitarão ao prosseguimento de estudos na educação superior.

Parágrafo único. Os cursos de educação profissional técnica de nível médio, nas formas articulada concomitante e subsequente, quando estruturados e organizados em etapas com terminalidade, possibilitarão a obtenção de certificados de 
qualificação para o trabalho após conclusão, com aproveitamento, de cada etapa que caracterize uma qualificação para o trabalho (BRASIL, 2008).

Essa mesma Lei n. 11.741/2008 também introduziu um parágrafo 3o no Art. 37 da LDB de 1996, na Seção V, que trata da Educação de Jovens e Adultos, para definir que "a Educação de Jovens e Adultos deverá articular-se, preferencialmente, com a educação profissional, na forma do regulamento".

A análise dessa legislação mostra que o sistema de educação profissional técnico de nível médio brasileiro, na prática, é uma espécie de sistema dual, que utiliza as escolas e as instituições especializadas.

O Quadro a seguir reproduz as informações trazidas pelas Diretrizes Curriculares Nacionais para Educação Profissional Técnica de Nível Médio, definidas pelo Parecer do Conselho Nacional de Educação/Câmara de Educação Básica (CNE/CEB) n. 11/2012, e mostra as formas de oferta definidas e suas correspondentes cargas horárias.
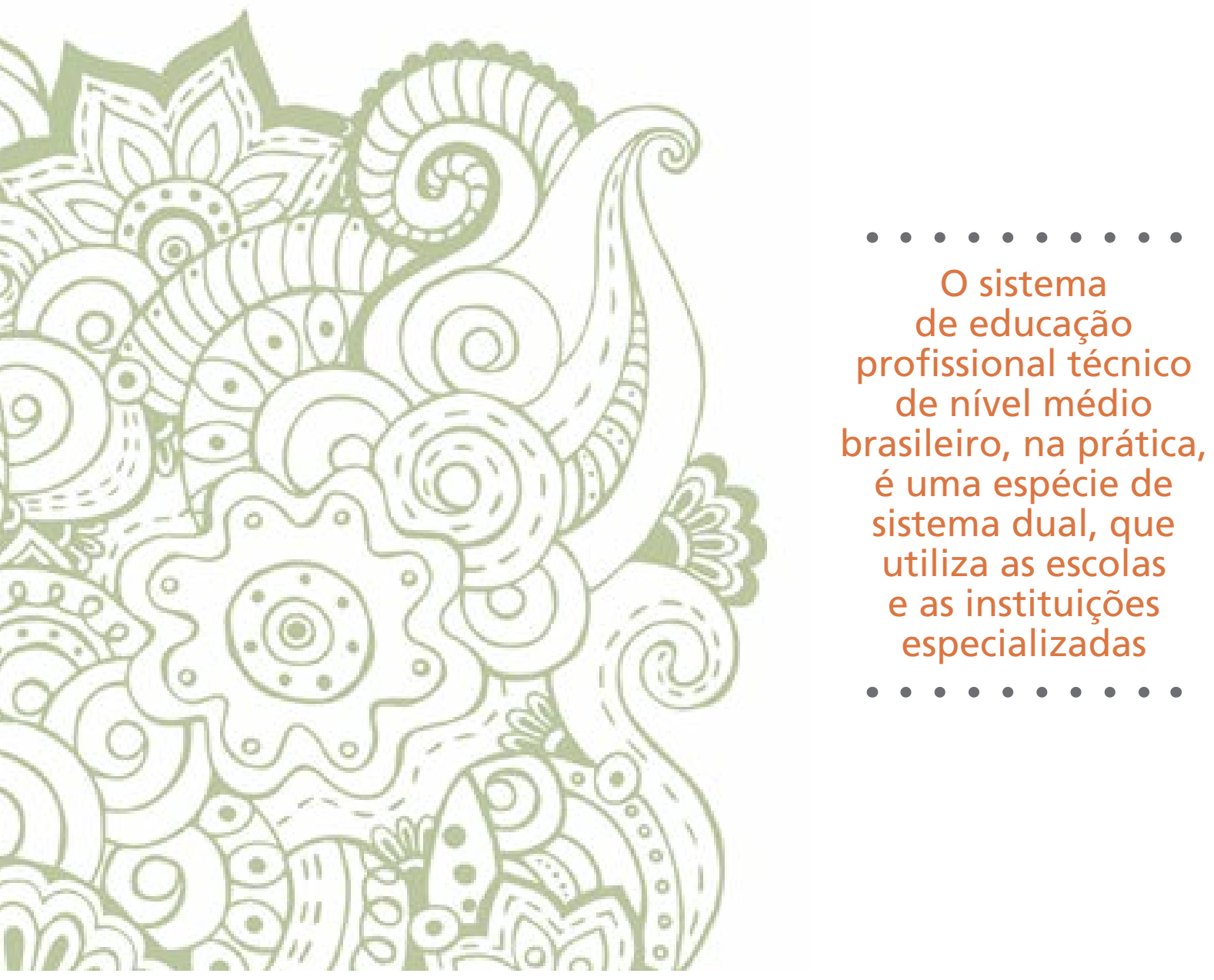

B. Téc. Senac, Rio de Janeiro, v. 43, n. 1, p. 78-109, jan./abr. 2017. 


\section{Quadro 1 - Formas de oferta de educação profissional técnica de nível médio}

\begin{tabular}{|c|c|c|}
\hline Forma & Oferta & Horas \\
\hline \multirow{3}{*}{ 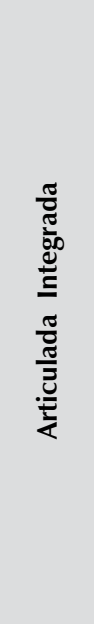 } & $\begin{array}{l}\text { Integrada com o ensino médio } \\
\text { regularmente oferecido, na idade } \\
\text { própria, no mesmo estabelecimento } \\
\text { de ensino. }\end{array}$ & $\begin{array}{c}\text { Mínimo de } 3.000,3.100 \text { ou } 3.200 \\
\text { horas, para a escola e para o estudante, } \\
\text { conforme a habilitação profissional } \\
\text { ofertada. }\end{array}$ \\
\hline & $\begin{array}{l}\text { Integrada com o ensino médio } \\
\text { na modalidade de Educação de } \\
\text { Jovens e Adultos (EJA) no mesmo } \\
\text { estabelecimento de ensino. }\end{array}$ & $\begin{array}{c}\text { Mínimo de } 800,1.000 \text { ou } 1.200 \text { horas, } \\
\text { conforme a habilitação profissional } \\
\text { ofertada, acrescida de mais } 1.200 \text { horas } \\
\text { destinadas à parte da formação geral, } \\
\text { totalizando mínimos de } 2.000 \text {, ou } 2.200 \\
\text { ou } 2.400 \text { horas para a escola e } \\
\text { para o estudante. }\end{array}$ \\
\hline & $\begin{array}{l}\text { Integrada com o ensino médio no } \\
\text { âmbito do Programa Nacional de } \\
\text { Integração da Educação Profissional } \\
\text { com a Educação Básica na } \\
\text { Modalidade de Educação de Jovens } \\
\text { e Adultos (Proeja) }\end{array}$ & $\begin{array}{c}\text { Mínimos de } 800,1.000 \text { ou } 1.200 \text { horas, } \\
\text { conforme a habilitação profissional } \\
\text { ofertada, acrescidas de } 1.200 \text { horas } \\
\text { para a formação geral, devendo sempre } \\
\text { totalizar } 2.400 \text { horas para a escola e para } \\
\text { o estudante. }\end{array}$ \\
\hline \multirow{3}{*}{ 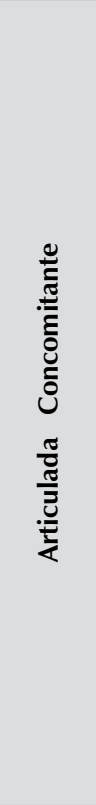 } & $\begin{array}{l}\text { Concomitante como o ensino } \\
\text { médio regular, na idade própria, em } \\
\text { instituições de ensino distintas, mas } \\
\text { com projeto pedagógico unificado, } \\
\text { mediante convênio ou acordo de } \\
\text { intercomplementaridade. }\end{array}$ & $\begin{array}{c}\text { Mínimo de } 3.000,3.100 \text { ou } 3.200 \text { horas, } \\
\text { para as escolas e para o estudante, } \\
\text { conforme habilitação profissional } \\
\text { ofertada, similar à oferta na forma } \\
\text { articulada. }\end{array}$ \\
\hline & $\begin{array}{l}\text { Concomitante com } \\
\text { o ensino médio regular, na mesma } \\
\text { instituição de ensino ou em } \\
\text { instituições de ensino distintas, } \\
\text { aproveitando-se as oportunidades } \\
\text { educacionais disponíveis. }\end{array}$ & $\begin{array}{c}\text { Mínimo de } 800,1.000 \text { ou } 1.200 \text { horas, } \\
\text { conforme habilitação profissional } \\
\text { ofertada, na instituição de educação } \\
\text { profissional e tecnológica, acrescida de } \\
\text { mais } 2.400 \text { horas na umidade escolar de } \\
\text { ensino médio, totalizando os mínimos de } \\
3.200,3.400 \text { ou } 3.600 \text { horas } \\
\text { para o estudante. }\end{array}$ \\
\hline & $\begin{array}{l}\text { Concomitante com o ensino } \\
\text { médio na modalidade EJA, na } \\
\text { mesma instituição de ensino ou } \\
\text { em instituições de ensino distintas, } \\
\text { aproveitando-se as oportunidades } \\
\text { educacionais disponíveis. }\end{array}$ & $\begin{array}{l}\text { Mínimos de } 800,1.000 \text { ou } 1.200 \\
\text { horas, conforme habilitação profissional } \\
\text { ofertada, na instituição de educação } \\
\text { profissional e tecnológica, acrescidas de } \\
\text { mais } 1.200 \text { horas na unidade escolar } \\
\text { de ensino médio na modalidade EJA, } \\
\text { totalizando } 2.000,2.200 \text { ou } 2.400 \text { horas } \\
\text { para o estudante. }\end{array}$ \\
\hline 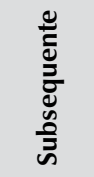 & $\begin{array}{c}\text { Educação profissional técnica } \\
\text { de nível médio ofertada após a } \\
\text { conclusão do ensino médio regular } \\
\text { ou na modalidade EJA. }\end{array}$ & $\begin{array}{l}\text { Mínimo de } 800,1.000 \text { ou } 1.200 \text { horas } \\
\text { para o estudante, conforme habilitação } \\
\text { profissional ofertada na instituição de } \\
\text { educação profissional e tecnológica. }\end{array}$ \\
\hline
\end{tabular}

Fonte: Conselho Nacional de Educação (2012).

As Diretrizes Curriculares Nacionais para Educação Profissional Técnica de Nível Médio, elaboradas pelo Conselho Nacional de Educação, além de ratificar as determinações da LDB, estabelecem, no Art. 6 o da Resolução CNE/ CEB n. 06/2012, que a educação profissional deve seguir, entre outros, os seguintes princípios: 
I - relação e articulação entre a formação desenvolvida no Ensino Médio e a preparação para o exercício das profissões técnicas, visando à formação integral dos estudantes;

II - respeito aos valores estéticos, políticos e éticos da educação nacional, na perspectiva do desenvolvimento para a vida social e profissional;

III - trabalho assumido como princípio educativo, tendo sua integração com a ciência, a tecnologia e a cultura como base da proposta político-pedagógica e do desenvolvimento curricular;

IV - articulação da Educação Básica com a Educação Profissional e tecnológica, na perspectiva da integração entre saberes específicos para a produção do conhecimento e a intervenção social, assumindo a pesquisa como princípio pedagógico;

V - indissociabilidade entre educação e prática social, considerando-se a historicidade dos conhecimentos e dos sujeitos da aprendizagem;

VI - indissociabilidade entre teoria e prática no processo de ensino-aprendizagem;

VII - interdisciplinaridade assegurada no currículo e na prática pedagógica, visando à superação da fragmentação de conhecimentos e de segmentação da organização curricular;

VIII - contextualização, flexibilidade e interdisciplinaridade na utilização de estratégias educacionais favoráveis à compreensão de significados e à integração entre a teoria e a vivência da prática profissional, envolvendo as múltiplas dimensões do eixo tecnológico do curso e das ciências e tecnologias a ele vinculadas (CONSELHO NACIONAL DE EDUCAÇÃO, 2012).

Os cursos de educação profissional técnica de nível médio são organizados por eixos tecnológicos constantes no Catálogo Nacional de Cursos Técnicos, instituído e organizado pelo Ministério da Educação, contemplando uma ou mais ocupações da Classificação Brasileira de Ocupações (CBO).

Os Catálogos Nacionais da Educação Profissional, tanto de cursos técnicos de nível médio quanto de cursos superiores de graduação em tecnologia, reúnem os cursos a partir dos seguintes eixos tecnológicos:

- Ambiente e Saúde

- Controle e Processos Industriais

- Desenvolvimento Educacional e Social

- Gestão e Negócios

- Informação e Comunicação

- Infraestrutura 
- Militar

- Produção Alimentícia

- Produção Cultural e Design

- Produção Industrial

- Recursos Naturais

- Segurança

- Turismo, Hospitalidade e Lazer

\section{O estado da educação profissional técnica de nível médio no Brasil}

De modo semelhante ao que ocorre em outros países, a educação profissional técnica de nível médio, no Brasil, passa por um processo de avaliação e sofre constante pressão para crescer e melhorar sua qualidade.

As matrículas vêm sendo ampliadas, porém, o total ainda é considerado insuficiente. $\mathrm{O}$ atendimento e a qualidade da educação profissional técnica de nível médio é diretamente afetado pela qualidade da educação regular. Essa afirmação é facilmente verificável quando se observa que, das $10 \mathrm{mi}-$ Ihões de pessoas com idades entre 15 e 17 anos, apenas 5,3 milhões estão matriculadas no ensino médio. Mais de 3 milhões estão atrasadas, ou seja, matriculadas no ensino fundamental, e outras 1,7 milhão está fora da escola.

A compreensão desses resultados é facilitada se os mesmos forem analisados do ponto de vista da evolução histórica da educação brasileira.

As Escolas Técnicas Federais, que receberam diferentes denominações ao longo do tempo, foram criadas pelo Presidente Nilo Peçanha, em 1909, com a denominação de Escolas de Aprendizes Artífices.

O Decreto n. 7.566, de 23 de setembro de 1909, criou 19 escolas, em diferentes Unidades da Federação, destinadas ao ensino profissional primário gratuito. A missão dessas escolas era formar operários e contramestres mediante o ensino prático. Em 1926, foi estabelecido um currículo padronizado para essas escolas de aprendizes artífices. Em 1959, no governo Juscelino Kubitschek, as escolas industriais foram transformadas em Escolas Técnicas Federais.

O Serviço Nacional de Aprendizagem Industrial (Senai) foi criado em 1942, para atender às necessidades do desenvolvimento industrial e, inspirado no sucesso do Senai, em 1946, foi criado o Senac, para atender às exigências do desenvolvimento do comércio e da prestação de serviços. Ao longo da história, os Serviços Sociais Autônomos incorporaram outras instituições, para atendimento a outros setores econômicos. Atualmente, contam com 
uma ampla rede de escolas profissionais, laboratórios e centros tecnológicos espalhados por todo território nacional. A maioria dos cursos promovidos pelo chamado "Sistema S", além dos cursos técnicos de nível médio e de alguns cursos superiores de graduação em Tecnologia, são cursos de qualificação profissional, incluindo a formação inicial e continuada de trabalhadores, propiciando aperfeiçoamento profissional, ou seja, visam atualizar ou complementar os conhecimentos dos trabalhadores. O Senai, por exemplo, é considerado um dos cinco maiores complexos de educação profissional do mundo e o maior da América Latina. Os cursos do Senai formam profissionais para 28 áreas da indústria, em níveis que vão desde a iniciação profissional até a pós-graduação.

A Tabela 1 mostra a variação das matrículas na EPT por dependência administrativa nos anos de 2007 a 2013. Nessa tabela, pode-se verificar que, em 2013, o total de matrículas na educação profissional técnica de nível médio foi de 1.441.051 matrículas. Em 2014, o total de matrículas atingiu a cifra de 1.741.528, o que corresponde a um aumento superior a $23 \%$ em relação ao ano anterior. Quando comparadas com as matrículas no ensino médio regular, verifica-se que, em 2014, as matrículas na educação profissional técnica corresponderam a 22,2\% do total (7.832.029). Dessas matrículas, $48 \%$ foram nas instituições privadas e $52 \%$ nas públicas.

Tabela 1 - Variação de matrículas na EPT (2007-2013)

\begin{tabular}{|l|c|c|c|c|c|}
\hline \multirow{2}{*}{ Ano } & \multicolumn{5}{|c|}{ Matrículas de Educação Profissional por Dependência Administrativa } \\
\cline { 2 - 6 } & Total & Federal & Estadual & Municipal & Privada \\
\hline $\mathbf{2 0 0 7}$ & 780.162 & 109.777 & 253.194 & 30.037 & 387.154 \\
\hline $\mathbf{2 0 0 8}$ & 927.978 & 124.718 & 316.404 & 36.092 & 448.764 \\
\hline $\mathbf{2 0 0 9}$ & 1.036 .945 & 147.947 & 355.688 & 34.016 & 499.294 \\
\hline $\mathbf{2 0 1 0}$ & 1.140 .388 & 165.355 & 398.238 & 32.225 & 544.570 \\
\hline $\mathbf{2 0 1 1}$ & 1.250 .900 & 189.988 & 447.463 & 32.310 & 581.139 \\
\hline $\mathbf{2 0 1 2}$ & 1.362 .200 & 210.785 & 488.543 & 30.422 & 632.450 \\
\hline $\mathbf{2 0 1 3}$ & 1.441 .051 & 228.417 & 491.128 & 30.190 & 691.376 \\
\hline
\end{tabular}

Fonte: Inep (2014).

O crescimento das matrículas verificado no período da Tabela 1 é fruto de uma série de ações desenvolvidas pelo Governo Federal em parceria com as redes estaduais e com a iniciativa privada, em especial com as instituições do chamado "Sistema S". Esses números tendem a continuar crescendo visto que muitas escolas ainda estão em construção.

O Programa Brasil Profissionalizado foi criado pelo Decreto n. 6.302, de 12 de dezembro de 2007, com vistas a estimular o ensino médio integrado à educação profissional, enfatizando a educação científica e humanística, por meio da articulação entre formação geral e educação profissional no contexto dos arranjos produtivos e das vocações locais e regionais. 


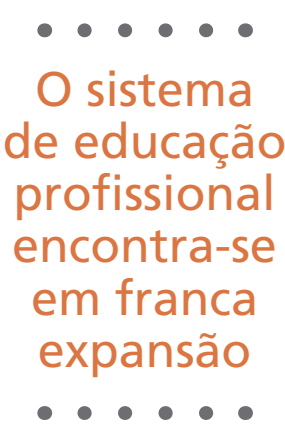

O Programa Brasil Profissionalizado presta assistência financeira aos estados para o desenvolvimento e a estruturação do ensino médio integrado à educação profissional mediante seleção e aprovação de propostas, formalizadas por meio da celebração de convênios.

Como resultado desse programa, muitos estados já inauguraram escolas de ensino profissionalizante, aumentando, assim, as matrículas nessa modalidade. Outras escolas estão em fase de construção.

O Plano de Expansão das Redes Federais, levado a efeito pelo Governo Federal a partir de 2003, concretizou a construção de mais de 500 unidades escolares. Recém-inauguradas, estão recebendo novos estudantes e esse processo resultará em significativo aumento das matrículas na educação profissional técnica de nível médio.

Paralelamente, as matrículas nos cursos destinados à formação inicial e continuada tiveram um grande impulso com a criação do Pronatec, que tem o objetivo de expandir, interiorizar e democratizar a oferta de cursos de educação profissional e tecnológica no país. Esse programa de governo integra o desenvolvimento de cinco iniciativas: a expansão da Rede Federal de Educação Profissional, Científica e Tecnológica; o Programa Brasil Profissionalizado; A Rede e-Tec Brasil; o Acordo de Gratuidade com os Serviços Nacionais de Aprendizagem e a Bolsa Formação.

Os cursos para qualificação profissional de trabalhadores possuem cargas horárias que variam de 160 a 400 horas. O Guia Pronatec de Cursos (BRASIL, 2016) apresenta 646 denominações de cursos, com as respectivas cargas horárias, a definição do perfil profissional e as ocupações respectivamente associadas. De acordo com o Ministério da Educação, de 2011 a 2015, por meio do Pronatec, foram realizadas 9,4 milhões de matrículas (BRASIL, 2016).

Em resumo, o sistema de educação profissional encontra-se em franca expansão. O crescimento do número de matrículas traz novos desafios que necessitam ser enfrentados para que essa expansão seja feita de forma sustentável.

\section{Desafios da educação profissional técnica de nível médio}

Relatórios produzidos por organizações como a OCDE, o Banco Mundial e a Unesco têm apontado que, diante dos desequilíbrios causados pelas mudanças das formas de produção, os sistemas educacionais necessitam promover 
reformas na educação secundária para evitar que a falta de qualificação para o trabalho sirva de motivo para o aumento do desemprego.

Entre as principais recomendações trazidas por esses relatórios, encontra-se a de que os indivíduos invistam em suas qualificações e que os sistemas de ensino aumentem a oferta de educação profissional, ofereçam cursos que despertem a capacidade de trabalhar em grupo e que ofereçam cursos mais generalistas, que permitam aos formandos mudar de emprego com mais facilidade e habilitem os indivíduos para sobreviver nos ambientes competitivos. Sugerem também que os sistemas aumentem a aproximação com o setor produtivo e sejam trabalhadas a atratividade e a valorização da educação profissional.

Confrontando essas recomendações com o caso brasileiro, verifica-se a necessidade de uma contextualização que permita considerar a educação profissional no Brasil em uma história que, nos últimos anos, vem passando por grandes transformações.

Os desafios da educação profissional técnica de nível médio no Brasil, a exemplo do que acontece em outras partes do mundo, guarda uma relação de semelhança com os desafios gerais dos jovens e são dependentes de fatores que vão além da escola. O número de matrículas oferecidas ainda é pequeno e o prestígio da educação profissional também é baixo. A educação profissional depende fortemente da educação geral que, por sua vez, é fraca.

De acordo com a PNAD 2013, a população brasileira de jovens de 15 a 29 anos é de 48,8 milhões de indivíduos (IBGE, 2014). Esse valor representa $24,3 \%$ da população do país. Desse total, 21\% estão na faixa de 15 a 17 anos, $46 \%$ na faixa de 18 a 24 anos e 33\% na faixa de 25 a 29 anos. Estudos mostram que a população brasileira começará a diminuir a partir do ano 2050, até quando continuará a crescer, devendo atingir o total de 233 milhões de habitantes.

Pesquisa de opinião realizada pela Secretaria Nacional da Juventude (SNJ), em 2013, mostrou que quando perguntados sobre o que gostariam que acontecesse em suas vidas para que se sentissem realizados, $48 \%$ dos jovens brasileiros (15 a 29 anos) marcaram a alternativa trabalho/emprego. A mesma pesquisa encontrou que, no entendimento desses jovens, as qualidades mais importantes para conseguir trabalho são experiência, nível de escolaridade e formação profissional. Quando perguntados sobre as ações que o governo deveria fazer para melhorar a situação dos jovens no trabaIho, marcaram pela ordem as alternativas: oferecer formação profissional, aumentar a escolaridade e a qualidade do ensino e apoiar a entrada no mercado de trabalho. 
Esses dados sugerem que, além dos desafios comuns aos outros países, o Brasil tem desafios que decorrem da questão demográfica e do acesso incompleto à educação geral que prevalece hoje em dia. A não universalização da educação geral constitui um ponto de estrangulamento para profissionalização.

O PNE 2014-2024, aprovado pela Lei n. 13.005, de 25 de julho de 2014, estabelece metas para a ampliação da educação profissional técnica de nível médio:

Meta 10 - Oferecer, no mínimo, 25\% das matrículas de educação de jovens e adultos, nos ensinos fundamental e médio, na forma integrada à educação profissional;

\section{$[\ldots]$}

Meta 11 - Triplicar as matrículas de educação profissional técnica de nível médio, assegurando a qualidade da oferta e pelo menos 50\% da expansão no segmento público (BRASIL, 2014).

As metas definidas no PNE não traduzem a totalidade dos desafios da educação profissional porque, para além da necessidade de expansão, faz-se necessário discutir, entre outros assuntos, o valor social da educação profissional técnica e a criação de mecanismos para o aumento da atratividade das carreiras profissionais.

A análise de documentos recentes que tratam da elaboração de políticas públicas para educação profissional técnica leva à identificação dos seguintes desafios:

I - Aumentar a atratividade e o prestígio da educação profissional;

II - Ampliar a articulação da educação básica com a educação profissional técnica;

III - Redimensionar os currículos da educação profissional técnica;

IV - Melhorar a articulação com o setor produtivo;

$\mathrm{V}$ - Fortalecer e reestruturar o sistema de financiamento;

VI - Melhorar a gestão das escolas e dos sistemas;

VII - Reconhecer a educação profissional a distância;

VIII - Estimular o reconhecimento de saberes e competências profissionais mediante certificação;

IX - Definir uma política para formação de professores para educação profissional;

$X$ - Desenvolver um sistema de avaliação específico para educação profissional técnica; 
XI - Construir estratégias de inovação que compatibilizem a formação cidadã com a inserção profissional do trabalhador.

\subsection{Atratividade da EPT}

Pesquisa realizada pela Secretaria Nacional de Juventude (2013) mostra que $48 \%$ dos jovens consultados colocam trabalho/emprego e educação/escola como objetivos para realização de suas vidas.

Essa informação leva ao convencimento de que tão importante quanto meIhorar a atratividade da educação profissional é aumentar a sua oferta. Nesse sentido, as metas 10 e 11 do PNE, citadas anteriormente, apontam na direção correta. Cabe cuidar para que as mesmas sejam alcançadas com qualidade.

O PNE traz estratégias para o atingimento das metas 10 e 11, entre as quais se destacam: para Meta 10 - manter o programa de educação de jovens e adultos voltado para a conclusão do ensino fundamental; incentivar as matrículas na educação de jovens e adultos, de modo a articular a formação inicial e continuada de trabalhadores com a educação profissional, objetivando à elevação do nível de escolaridade dos trabalhadores; implantar programa nacional de reestruturação e aquisição de equipamentos voltados à expansão e à melhoria da rede física de escolas públicas que atuam na educação integrada à educação profissional; estimular a diversificação curricular da educação de jovens e adultos, articulando a formação básica e a preparação para o mundo do trabalho e estabelecendo inter-relações entre teoria e prática; fomentar a produção de material didático e implementar mecanismos de reconhecimento de saberes dos jovens e adultos trabalhadores, a serem considerados na articulação curricular dos cursos de formação inicial e continuada e dos cursos técnicos de nível médio (BRASIL, 2014).

Para triplicar as matrículas da educação profissional técnica de nível médio, ou seja, para o atingimento da Meta 11, o PNE elencou estratégias, entre as quais se destacam: expandir as matrículas na Rede Federal de Educação Profissional; fomentar a expansão da oferta nas redes estaduais; fomentar a expansão da oferta na modalidade educação a distância (EAD); expandir a oferta de financiamento estudantil à educação profissional técnica de nível médio oferecida em instituições privadas de nível superior e expandir o atendimento de ensino médio gratuito integrado à educação profissional para população do campo e para comunidades indígenas e quilombolas (BRASIL, 2014).

O aumento da atratividade pela via da ampliação da oferta vem sendo efetivado por meio da construção de novas escolas técnicas e da entrada de

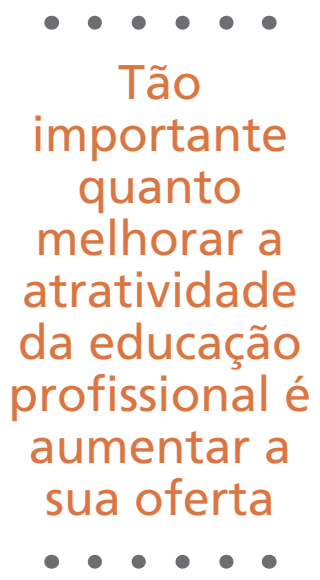


novas secretarias estaduais no sistema de formação profissional, mediante adesão ao Programa Brasil Profissionalizado.

A valorização dos profissionais de nível médio constitui-se um passo adiante, visto que existe uma excessiva valorização da educação superior, notadamente da educação bacharelesca.

\subsection{Articulação da educação profissional técnica com a educação básica regular}

De acordo com o Artigo 40 da LDB, a educação profissional será desenvolvida em articulação com o ensino regular.

Às escolas regulares de ensino médio cabe a preparação geral para o trabaIho, enquanto às instituições especializadas em educação profissional cabe a habilitação profissional.

A habilitação profissional, quando oferecida pela escola de ensino médio de forma facultativa, não pode servir de desculpa para o não cumprimento de sua finalidade precípua que é a de propiciar a formação geral do educando.

As Diretrizes Curriculares Nacionais para o Ensino Médio e as Diretrizes Curriculares Nacionais para Educação Profissional Técnica de Nível Médio (CONSELHO NACIONAL DE EDUCAÇÃO, 2012) definem a articulação que deve haver entre as duas modalidades quando estabelecem que "garantido o ensino médio obrigatório, as escolas podem preparar para o exercício de profissões específicas" e complementam afirmando que a oferta de educação profissional pode ser feita de forma articulada ou subsequente, podendo, ainda, a articulada ser feita de forma integrada ou concomitante.

Resulta patente, de acordo com a legislação vigente, que a educação profissional é uma opção que pode ser exercida pelo estudante.

Para viabilizar a oferta de habilitações profissionais, as mantenedoras, tanto das redes públicas como das redes privadas, devem efetuar um diagnóstico das necessidades, possibilidades e consequências da oferta das mesmas. O passo seguinte pode ser a efetuação de parcerias capazes de viabilizar os projetos escolhidos.

A experiência tem mostrado que as dificuldades que se apresentam devem-se mais à falta de condições das escolas e à falta de professores especializados para o desenvolvimento dos currículos propostos, do que à falta de normatização. 


\subsection{Interação com o setor produtivo}

Estudos recentes mostram que a relação de causa e efeito entre a qualificação profissional e a empregabilidade, muitas vezes, propagada como absoluta, é menos eficiente do que o esperado. Essa relação depende de fatores que estão fora da escola, tais como política industrial e adoção de novas tecnologias pelas indústrias, especulação financeira e relações comerciais entre países.

Desse modo, a aproximação com o setor produtivo deve ser feita no sentido de facilitar a prática de estágios e outras interações, sem, no entanto, gerar grandes expectativas referentes a empregos, mas com vistas à melhoria da qualidade geral da educação profissional. As normas que tratam de estágios necessitam ser aperfeiçoadas no sentido de viabilizar que as empresas possam receber um número maior de estudantes.

A carga horária que for destinada ao estágio profissional supervisionado deve ser adicionada à carga horária total do respectivo curso, salvo em curso na forma articulada, integrado com o ensino médio na modalidade de educação de jovens e adultos, no âmbito do Proeja, que obedece a regras próprias. A instituição educacional, o estudante e a organização concedente da atividade de estágio profissional supervisionado devem, conjuntamente, firmar termo de compromisso, conforme preceitua a Lei.

\subsection{Financiamento}

Por exigir laboratórios e equipamentos e, ainda, por requerer maior diversidade de profissionais, a educação profissional resulta mais dispendiosa do que a educação geral. Isso faz com que alguns sistemas prefiram investir na oferta de educação geral.

Para evitar que essas escolhas causem dificuldades para a necessária ampliação da oferta, convém promover uma discussão sobre as formas de financiamento, notadamente, sobre a distribuição dos recursos do Fundo de Manutenção e Desenvolvimento da Educação Básica e de Valorização dos Profissionais da Educação (Fundeb), de modo que os recursos para educação profissional sejam contemplados de forma adequada.

\subsection{Educação a distância}

A LDB oficializou a modalidade de educação a distância como válida em todos os níveis e modalidades de ensino, exceto para o ensino fundamental, o qual deve ser presencial. Por outro lado, define que o ensino a distância, no 
ensino fundamental, pode ser utilizado como complementação da aprendizagem, ou ainda, em situações de emergência.

O Decreto n. 5.622/2005 caracteriza a EAD como modalidade educacional na qual a mediação didático-pedagógica nos processos de ensino e aprendizagem ocorre com a utilização de meios e tecnologias de informação e comunicação, com estudantes e professores desenvolvendo atividades educativas em lugares e/ou tempos diversos (BRASIL, 2005).

Todos os princípios e concepções que orientam a educação profissional presencial devem ser considerados na oferta da modalidade de educação a distância. Os cursos que podem ser ofertados estão listados no Catálogo Nacional de Cursos Técnicos de Nível Médio. Os projetos pedagógicos dos cursos de EAD também podem prever acompanhamento pedagógico, práticas em laboratórios e estágio supervisionado e trabalho de conclusão de curso. Devem definir os momentos presenciais e as formas de avaliação.

A supervisão dos processos presencial e a distância, a eficiência dos sistemas de comunicação e informação, a qualidade do material didático e a organização dos ambientes específicos de aprendizagem são definitivos para garantia da qualidade dos cursos a distância. Faz-se necessário, além disso, garantir o apoio e acompanhamento dos estudantes durante suas trajetórias formativas.

A presença de profissionais capacitados nos conteúdos dos componentes curriculares é outra exigência fundamental. Nos momentos a distância, o acompanhamento é realizado por meio das plataformas virtuais de ensino, videotutoria, diferentes meios de comunicação síncrona e assíncrona, além de outros recursos.

Ao regular a matéria, o Decreto n. 5.622/2005 apenas menciona, mas não define, nos cursos técnicos, carga horária reservada para avaliações, estágios supervisionados obrigatórios e atividades que exigem laboratórios ou outros ambientes específicos, bem como não define os tempos para os momentos presenciais.

A Resolução CNE/CEB n. 01/2016, com fundamento no Parecer CNE/CEB n. $13 / 2015$, bem como no Decreto n. 5.622/2005, com a redação dada pelo Decreto n. 6.303/2007, seguindo orientação do Artigo 211 da Constituição federal e Artigo 8o da Lei n. 9.394/1996, em obediência ao Artigo 90 da LDB, definiu Diretrizes Operacionais Nacionais para o credenciamento institucional e a oferta de cursos e programas de ensino médio, de educação profissional técnica de nível médio e de educação de jovens e adultos, nas etapas do ensino fundamental e do ensino médio, na modalidade de educação a distância, em regime de colaboração entre os sistemas de ensino. 
A referida Resolução esclarece pontos relativos à carga horária destinada a estágios e à avaliação.

De acordo com tais orientações normativas, o estágio supervisionado deve ser presencial em sua totalidade, quando previsto, e nos termos do plano do curso. Sua carga horária é acrescida à prevista para a habilitação oferecida nos termos do Catálogo Nacional de Cursos Técnicos, assim como os tempos das avaliações finais que forem realizados. As atividades de prática profissional integram a carga horária da habilitação. Quanto à carga horária obrigatória para os momentos presenciais, devem ser estabelecidos parâmetros, distinguindo-se os cursos do segmento da Saúde dos demais. Os da Saúde requerem um mínimo de $50 \%$ de atividades presenciais. Nos demais cursos, admite-se uma variação entre $20 \%$ e 50\%, dependendo da natureza tecnológica dos cursos e do perfil profissional de conclusão desejado para cada curso de educação profissional técnica de nível médio.

\subsection{Redimensionamento dos currículos}

Para acompanhar as demandas colocadas pelo mundo do trabalho, o currículo da educação profissional deve superar a tradicional redução da preparação para o trabalho focada meramente no aspecto operacional e garantir a presença de elementos essenciais da formação geral do cidadão.

O currículo deve propiciar que a formação profissional seja integrada à formação geral. Antes de aprender o ofício específico, o trabalhador necessita obter uma formação básica que o credencie para o exercício da cidadania.

Uma formação integral não somente possibilita o acesso a conhecimentos científicos e tecnológicos, mas também promove a reflexão crítica sobre os padrões culturais e as referências estéticas que se manifestam em tempos e espaços históricos.

As Diretrizes Curriculares Nacionais para Educação Profissional Técnica de Nível Médio sugerem que os currículos sejam organizados tendo em vista as quatro dimensões da formação humana: o trabalho, a ciência, a tecnologia e a cultura. É nessa perspectiva que os cursos de educação profissional técnica de nível médio são organizados por eixos tecnológicos constantes do Catálogo Nacional de Cursos Técnicos de Nível Médio.

No tocante à adequação dos currículos, é necessário investir na oferta de cursos mais gerais, que permitam que o egresso seja aproveitado em mais de uma tarefa específica, aumentando, assim, as possibilidades de emprego. 


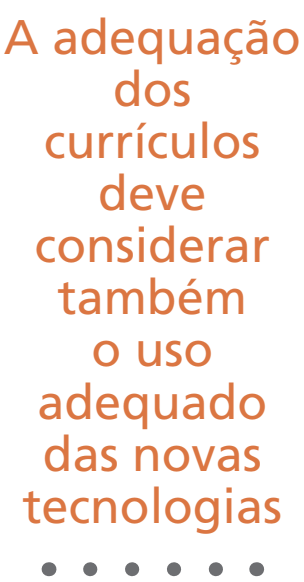

A adequação dos currículos deve considerar também o uso adequado das novas tecnologias de informação e comunicação em sala de aula e no desenvolvimento de atividades não presenciais.

Os novos currículos devem privilegiar o desenvolvimento de atividades que permitam e estimulem o aprender a aprender.

\subsection{Formação de professores}

A LDB define no seu Artigo 62 que a formação de docentes para atuar na educação básica far-se-á em nível superior, em cursos de licenciatura, de graduação plena, em universidades e institutos superiores de educação, admitida, no entanto, como formação mínima para o exercício do magistério na educação infantil e nos cinco primeiros anos do ensino fundamental, a oferecida em nível médio na modalidade normal.

A exigência de licenciatura plena coloca dificuldades para os sistemas de ensino que têm a tarefa de oferecer os cursos de educação profissional, uma vez que a montagem de tais cursos requer um número significativo de disciplinas especializadas para as quais não há profissionais licenciados em quantidade suficiente.

Por isso, é urgente que a União, responsável pela coordenação da política nacional de educação, efetue uma discussão sobre os mecanismos de formação e contratação de professores para educação profissional, notadamente, para as disciplinas técnicas específicas.

A questão da formação de professores para educação profissional deve ser encarada tendo em vista que há especificidade que distingue a formação de docentes para a educação básica regular da formação de docentes para educação profissional. O professor da educação profissional deve estar apto a preparar o cidadão para saber trabalhar em um contexto profissional cada vez mais complexo e exigente. Esta é uma variável de fundamental importância para distinguir a formação desse professor da educação profissional daquele outro da educação básica de modo geral.

O professor da educação profissional deve exibir tanto o bom domínio dos saberes pedagógicos necessários parar conduzir jovens e adultos nas trilhas da aprendizagem e da constituição de saberes e competências profissionais quanto o adequado domínio dos diferentes saberes disciplinares do campo específico de sua área de conhecimento, para poder fazer escolhas relevantes dos conteúdos, que devem ser ensinados e aprendidos, para que os formandos tenham condições de responder, de forma original e criativa, aos desafios diários de sua vida profissional e pessoal, como cidadão trabaIhador. A formação do professor da educação profissional não trata apenas 
de garantir o domínio dos chamados conhecimentos disciplinares, os quais podem, muito bem, ser adquiridos em cursos de graduação, tanto no bacharelado quanto na tecnologia, ou até mesmo em cursos técnicos de nível médio, trata também da aquisição de conhecimentos pedagógicos e de conhecimentos referentes à dinâmica do mundo do trabalho.

A educação profissional requer a presença de profissionais que estejam vinculados diretamente com o mundo do trabalho no setor produtivo objeto do curso. Entretanto, os mesmos precisam estar adequadamente preparados para o exercício da docência, tanto em relação à sua formação inicial quanto à formação continuada e permanente, pois o desenvolvimento dos cursos técnicos deve estar sob responsabilidade de especialistas no segmento profissional, com conhecimentos didático-pedagógicos pertinentes para orientar seus alunos nas trilhas do desenvolvimento da aprendizagem e da constituição dos saberes profissionais.

Faz-se necessário desenvolver, com urgência, uma política de formação de professores para educação profissional capaz de dar suporte ao crescimento das matrículas que vem ocorrendo nessa modalidade educacional.

\subsection{Avaliação da educação profissional técnica de nível médio}

O artigo 41 da LDB estabelece que: "O conhecimento adquirido na educação profissional e tecnológica, inclusive no trabalho, poderá ser objeto de avaliação, reconhecimento e certificação para prosseguimento ou conclusão de estudos" (BRASIL, 1996).

As Diretrizes Curriculares Nacionais Gerais para Educação Básica indicam três dimensões básicas de avaliação: avaliação da aprendizagem, avaliação institucional interna e externa e avaliação de redes de educação básica.

A avaliação da aprendizagem deve ser desenvolvida pela escola, em concordância com seu projeto pedagógico, e deve assumir caráter educativo, de modo a viabilizar ao estudante a condição de analisar seu percurso e, ao professor e à escola, identificar dificuldades e potencialidades individuais e coletivas. No caso da educação profissional, a avaliação deve valorizar o acompanhamento das atividades relacionadas com o desenvolvimento da atividade profissional relacionada com o curso em desenvolvimento. 
Já a avaliação institucional interna é realizada a partir da proposta pedagógica da escola, assim como seu plano de trabalho, que deve ser avaliado sistematicamente, de maneira que a instituição possa analisar seus avanços e localizar seus aspectos que merecem reorientação. No caso das escolas de educação profissional, cabe avaliar, entre outros aspectos, as questões relacionadas com a empregabilidade e com o atendimento às demandas do mundo do trabalho.

No tocante à avaliação das redes de ensino, que é responsabilidade do Estado, cabe desenvolver um sistema de avaliação da educação profissional que contemple os critérios utilizados na educação básica regular, mas seja também capaz de captar as especificidades da formação profissional.

Tal sistema deve considerar a adequação dos currículos às necessidades das empresas, a empregabilidade dos egressos e a cultura de trabalho obtida pelos estudantes.

\section{Considerações finais}

A evolução recente da educação profissional técnica de nível médio, no Brasil, leva a crer que o Sistema de Educação Profissional está devidamente capacitado para enfrentar os desafios que estão colocados. O aparato normativo favorece a flexibilização curricular e organizacional, a sociedade está convencida da importância da EPT para o desenvolvimento do país, as instituições públicas e privadas estão ampliando a oferta e o setor empresarial está buscando, cada vez mais, a incorporação de profissionais qualificados.

O enfrentamento dos desafios identificados passa, principalmente, pela continuidade do financiamento, pela constante adequação dos currículos, pela valorização salarial dos profissionais de nível técnico e pelo investimento contínuo na formação de professores com qualificação específica para a educação profissional. 


\section{Referências}

BRASIL. Constituição (1988). Constituição da República Federativa do Brasil. Brasília, DF: Senado Federal, 1988.

BRASIL. Decreto n. 5.622, de 19 de dezembro de 2005. Regulamenta o art. 80 da Lei n. 9394, de 20 de dezembro de 1996, que estabelece as diretrizes e bases da educação nacional. Diário Oficial da União, Brasília, DF, 20 dez. 2005.

BRASIL. Decreto n. 7.566, de 23 de setembro de 1909. Créa nas capitaes dos Estados da Escolas de Aprendizes Artífices, para o ensino profissional primario e gratuito.

Coleção de Leis do Brasil, Rio de Janeiro, 1909. Disponível em: <http://portal.mec. gov.br/setec/arquivos/pdf3/decreto_7566_1909.pdf>. Acesso em: 22 fev. 2017.

BRASIL. Lei n. 9.394, de 20 de dezembro de 1996. Estabelece as diretrizes e bases da educação nacional. Diário Oficial da União, Brasília, DF, 23 dez. 1996.

BRASIL. Lei n. 11.741, de 16 de julho de 2008. Altera dispositivos da Lei n. 9.394, de 20 de dezembro de 1996. Diário Oficial da União, Brasília, DF, 2008.

BRASIL. Lei n. 13.005, de 25 de junho de 2014. Aprova o Plano Nacional de Educação - PNE e dá outras providências. Diário Oficial da União, Brasília, DF, 26 jun. 2014.

BRASIL. Ministério da Educação. Guia Pronatec de cursos FIC. 4. ed. Brasília, DF, 2016. Disponível em: <http://portal.mec.gov.br/index.php?option=com_ docman\&view=download\&alias=41261-guia-pronatec-de-cursos-fic-2016pdf\&category_slug=maio-2016-pdf\&ltemid=30192>. Acesso em: 22 fev. 2017.

CONSELHO NACIONAL DE EDUCAÇÃO (Brasil). Câmara de Educação Básica. Parecer CNE/CEB n. 5, de 4 de maio de 2011. Diretrizes Curriculares Nacionais para o Ensino Médio. Diário Oficial da União, Brasília, DF, 24 jan. 2012. Disponível em: <http://portal. mec.gov.br/index.php?option=com_docman\&view=download\&alias=8016-pceb00511\&category_slug=maio-2011-pdf\&ltemid=30192 >. Acesso em: 29 dez. 2016.

CONSELHO NACIONAL DE EDUCAÇÃO (Brasil). Câmara de Educação Básica. Parecer CNE/CEB n. 11/2012: aprovado em 9 de maio de 2012. Diretrizes Curriculares Nacionais para Educação Profissional Técnica de Nível Médio. Diário Oficial da União, Brasília, DF, 4 set. 2012. Seção 1, p. 98. Disponível em: <http://portal.mec.gov. br/index.php?option=com_content\&view=article\&id $=17576 \& \mid$ temid $=866>$. Acesso em: 22 fev. 2017.

CONSELHO NACIONAL DE EDUCAÇÃO (Brasil). Câmara de Educação Básica. Parecer CNE/CEB n. 13, de 11 de novembro de 2015. Reexame do Parecer CNE/CEB n. 2/2015, que reexaminou o Parecer n. 12/2012, que define as Diretrizes Operacionais Nacionais para a Oferta de Educação a Distância (EAD), no âmbito da Educação Básica, em regime de colaboração entre os sistemas de ensino. Diário Oficial da União, Brasília, DF, 28 jan. 2016. Seção 1, p. 19. Disponivel em: <http://portal.mec.gov.br/index. php?option=com_docman\&view=download\&alias $=27581$-pareceres-da-camara-deeducacao-basica-13-2015-pdf\&category_slug=novembro-2015-pdf\&ltemid=30192>. Acesso em: 3 mar. 2017. 
CONSELHO NACIONAL DE EDUCAÇÃO (Brasil). Câmara de Educação Básica. Resolução n. 6, de 20 de setembro de 2012. Define Diretrizes Curriculares Nacionais para a Educação Profissional Técnica de Nível Médio. Diário Oficial da União, Brasília, DF, 21 set. 2012. Seção 1, p. 22. Disponível em: <http://mobile.cnte.org.br:8080/legislacaoexterno/rest/lei/51/pdf>. Acesso em: 22 fev. 2017.

COORDENAÇÃO DE APERFEIÇOAMENTO DE PESSOAL DE NÍVEL SUPERIOR (Brasil). Plano Nacional de Pós-graduação: PNPG 2011-2020. Brasília, DF, 2010.

GALVÃO, A. C. F. Mestres e doutores, 2015: estudos da demografia da base técnicocientífica brasileira. Brasília, DF: Centro de Gestão e Estudos Estratégicos, 2016.

IBGE. Coordenação de Trabalho e Rendimento. Pesquisa Nacional por Amostra de Domicílios: síntese de indicadores 2013. Rio de Janeiro, 2014.

IBGE. Coordenação de Trabalho e Rendimento. Pesquisa Nacional por Amostra de Domicílios: síntese de indicadores 2014. Rio de Janeiro, 2015.

INEP. Censo escolar da educação básica 2013: resumo técnico. Brasília, DF, 2014. INEP. Sinopse estatística da educação básica 2015. Brasília, DF, 2016. Disponível em: <http:portal.inep.gov.br/básica-censo-escolar-sinopse-sinopse> . Acesso em: 29 dez. 2016.

SECRETARIA NACIONAL DE JUVENTUDE (Brasil). Pesquisa nacional sobre perfil e opinião dos jovens brasileiros. Brasília, DF, 2013. Disponível em: <https://issu.com/ secretariageralpr/docs/pesquisa_lan_amento_diagrama_0>. Acesso em: 3 mar. 2017.

SENAI. DN. Panorama mundial da educação profissional: desafios e respostas. Brasília, DF, 2015.

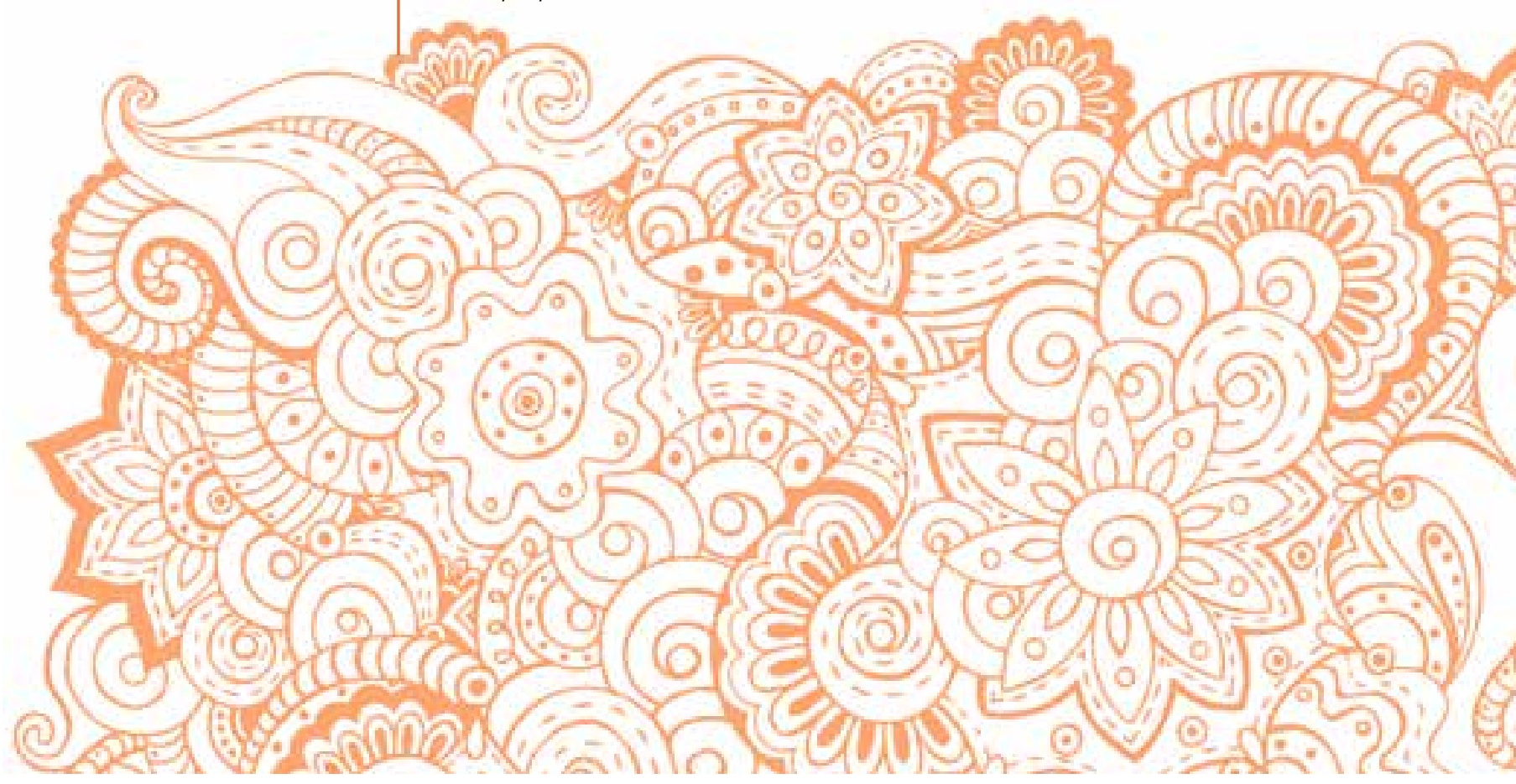

